\title{
CORRESPONDENCE/
}

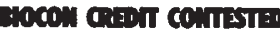

To the editor:

T $\mathrm{T}$ e were very interested in reading about the Biocon product now being manufactured in the Phillipines (Bio/Technology 5:772, Aug'87).

Your readers should be aware, however, that the development is hardly new and has been in the scientific and technical literature for some time. For example, A. K. Culbreath, R. Rodriguez-Kabana, and G. Morgan-Jones of Auburn University (Alabama) have published a paper titled "Chitin and Paecilomyces lilacinus for control of Meloidogyne arenaria" $(\mathrm{Ne}$ matropica 16(2): 153-166, 1986).

Robert Austin Milch President Igene Biotechnology Inc. 9110 Red Branch Road Columbia, MD 21045

\section{Tos Patur:ans:}

To the editor:

Tongratulations on presenting $\mathrm{Pe}$ Ater Duesberg's "Challenge to the AIDS Establishment" in the November 1987 issue. Although Dr. Duesberg's views regarding AIDS and oncogenes clearly run counter to prevailing scientific dogma, they are factually correct and merit more consideration than they have received from the scientific community, especially its more influential members.

Gordon Edlin

Professor of Genetics

University of California

Davis, CA 95616

\section{Nis porgang?}

To the editor:

There should be space available for critical comments about current scientific matters, such as November's Last Word by Peter Duesberg, "A Challenge to the AIDS Establishment." These critiques, however, should not be embellished by polemics and should, if possible, include all relevant, published biological data.

In his article, Duesberg fails to mention supportive data from animal studies. The attack of primates by what seems to be a closely related virus that causes similar disease states is, in my opinion, very supportive of the AIDS thesis. Further, diseases caused by similar viruses have been described in cats and cows.
One would like to know if the disease can be caused by exposure to the virus under relatively controlled conditions. Again, the author fails to mention the development of AIDS from accidental inoculation of scientific personnel. In at least two such instances, the inoculations involved viruses, not cells.

And many of Duesberg's other statements concerning $T$-cell pathology are debatable.

In brief, the author has failed to demolish the AIDS "hypothesis." Neither does he provide an alternative hypothesis. Those of us who care for AIDS patients are not part of an "AIDS Establishment" and certainly do not seek benefit from it; indeed we consider ourselves at some risk of personal harm. We seek thoughtful publications by our colleagues that may clarify this dread disease syndrome. We do not seek polemics.

George E. Moore, M.D., Ph.D.

Professor of Surgery

Chief, Division of Surgical Oncology Dept. of Health and Hospitals

645 Bannock St. - \#1806 Denver, CO 80204

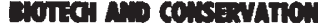

To the editor:

Much has been written of late 1 about the need to educate the public about the fundamentals of biotechnology. Although education is always a noble endeavor, the underlying assumption that education will bring enlightenment to those currently erecting legal barriers and launching political projectiles at the biotech industry is seriously flawed.

Misguided public debate on this issue is slowing the progress of science and technology in the United States and is beginning to impact our international competitiveness. Something surely must be done.

I am not the first to contend that the biotechnology industry's image is still suffering from the "Andromeda Strain" syndrome, and that this fear has continued to grow despite key scientific and political advances. Somewhere along the way, the public has cast biotechnology in the image of a group of anti-nature, anti-environment, anti-conservationists with an attendant disregard for the future of man and his environment, and a system of ethics that is doubtful at best.
The truth is that many biotechnologists have much in common with the very people who wish to inhibit the industry's advance. Indeed, many genetic engineers entered the field with strong backgrounds in biology and because of their love for the beauty and diversity of life-not because of a perverse and destructive desire to create some uncontrollable beast.

In fact, biotechnology can do more for improving our conservation/environmental efforts than any other technology. Three examples of this are the use of recombinant DNA methods to allow the degradation of xenobiotics; preserving threatened (and even extinct) species through gene banking; and advances in the development of nitrogen-fixing cash crops.

In my opinion, a shift in public support could best be achieved by a public relations campaign aimed at making alliances between the industry and broad-based conservation efforts, such as the Sierra Club and other public interest groups involved with world hunger and health. We need to create a new vision within which the two sides can unite and realize that they are in fact partners, not adversaries.

Kenneth D. Coleman, Ph.D. Stanford University

Graduate School of Business Stanford, CA 94305-5015

\section{Wus pioves mut}

To the editor:

Tould like to clarify the source of some of the materials used in the paper by D. Hussong et al. entitled "Viable Legionella pneumophila not detectable by culture on agar media" (Bio/Technology 5:947-950, Sept. '87).

I provided the L. pneumophila serogroup 1 isolated from Stafford (62210, 62211, 62212, and 62213) with the kind permission of Dr. I. D. Farrel of the Public Health Laboratory (Birmingham, U.K.). The monoclonal antibodies reported in table 1 , but not in the text, were kindly provided by Cogent Ltd.

P. I. L. Dennis

Public Health Laboratory Service Centre for Applied Microbiology \& Research Quality Control and Safety Laboratory Porton Down, Salisbury Wiltshire SP4 0JG, U.K. 